\title{
Investigation of Pre-Service Science Teachers' Attitudes towards Sustainable Environmental Education
}

\author{
Özgül Keleş ${ }^{1}$ \\ ${ }^{1}$ Faculty of Education, Department of Science Education, Aksaray University, Aksaray, Turkey \\ Correspondence: Özgül Keleş, Faculty of Education, Department of Science Education, Aksaray University, \\ Aksaray, 68100, Turkey. E-mail: ozgulkeles@gmail.com
}

Received: August 5, 2017

Accepted: August 15, 2017

Online Published: August 22, 2017

doi:10.5539/hes.v7n3p171

URL: http://doi.org/10.5539/hes.v7n3p171

\begin{abstract}
The purpose of the current study is to investigate pre-service science teachers' sustainable environmental education attitudes and the factors affecting them in terms of some variables (gender and grade level). The study group of the current research is comprised of 154 pre-service teachers attending the Department of Science Education in the Faculty of Education of Aksaray University. The study employed the descriptive survey method, one of the qualitative research methods. As the data collection tool, "The Sustainable Environmental Education Attitude Scale" developed by Afacan and Demirci Güler (2011) was used in the study. The Cronbach alpha reliability of the scale was calculated to be $\alpha=.93$. In the statistical analysis of the data, SPSS was used. In the analysis of the data, Independent Samples t-Test and One Way ANOVA were run. The analysis results revealed that sustainable environmental education attitudes frequency of the pre-service teachers is at the medium level. It was also found that the sustainable environmental education attitudes of the pre-service teachers do not vary significantly by gender; yet, they were found to be varying significantly depending on the grade level variable. It can be suggested that further research can attempt to determine the attitudes of pre-service teachers from different branches and to analyze different factors affecting sustainable environmental education attitude.
\end{abstract}

Keywords: sustainable environmental education, attitude, pre-service science teachers, gender, grade level

\section{Introduction}

Educational institutions play an important role in the process of building the knowledge, skills, awareness, values and sustainable action necessary to achieve the goal of sustainable earth. Educational institutions need to educate teachers who can better understand sustainability and help to bridge the gap between theory and education. This will play a key role in shaping future generations, enhancing sustainability activities and taking responsibility. Educational institutions and programs that will prepare teachers for sustainable education seem to be not doing their best. The education of teachers plays a vital role in achieving changes in teaching and learning in schools. Indeed, the professional development of pre-service teachers for sustainability is defined as priority over priorities. Teacher education is seen to be a key strategy not adequately exploited yet at schools for sustainability (Ferreira et al., 2009).

Educational institutions should take the leadership in this regard in order to make the leaders of future generations conscious and critical thinkers about sustainability. Climate change, $\mathrm{CO} 2$ emissions, poverty and other current environmental problems must influence these educational institutions so that they should prioritize sustainability education in the school curriculum. Sustainability education first requires a holistic approach for better understanding of sustainability-oriented actions in higher education and society (Gardner, 2017).

Although it is known that tertiary education institutions have a very high potential to affect changes in the field of sustainability (Corcoran \& Wals, 2004; Cortese, 2003; Wals \& Jickling, 2002), some research conducted in the field of education has showed that the Education for Sustainable Development (ESD) is not widely utilized (Christie et al., 2013); that there is a gap between instructional applications promoted in ESD literature and teachers' experiences (Cotton et al., 2007); that university instructors do not understand ESD well and have adequate resources and they behave like traditional instructors delivering traditional lessons (Thomas, 2004; as cited Tomas, Girgenti, \& Jackson, 2017). 
Education for Sustainable Development supports student-centered, transformative pedagogies that encourage learning through active, participatory and experiential learning. Traditional lectures provide limited opportunities for involving students in such pedagogies (Evans, Tomas, \& Woods, 2016). Nolet (2009) describes sustainability as a preparation paradigm emerging in the pre-service training of teachers. In order to integrate sustainability education into teachers' preparation, it should be connected with a framework dealing with special strategies, curriculum vision for teacher training, teachers' conceptions of learning, their tendencies and professional applications. It is emphasized that a new generation of teachers can be encouraging in solving the global, environmental and social justice challenges and can help to develop a curriculum vision addressing basic social goals of education. Ferreira et al. (2009) suggest that at the stage of ensuring sustainability in Australian schools, this is not possible without the preparation of teachers for this task.

Scientists put forward different views on educational curricula in education for sustainability. Orr (2003) emphasizes that the relationship between energy, the environment and the economy must be addressed in such a way as to apply it across disciplines; Moore (2005) argues that sustainability education should include social, ecological, economic, political and spiritual components of how students think about environmental problems and effective teaching strategies and different world views and perspectives and human impact on ecosystems should be discussed; Fleischer (2011); while focusing on the learning process, stresses that science education needs to be used to integrate a pedagogy that promotes practical knowledge with a moral and sustainable ideology by implementing an experiential, participatory and multidisciplinary approach; Lautensach and Lautensach (2010) propose a curriculum that focuses on values, attitudes and beliefs to facilitate sustainable behavior and environmental justice. Stuckey (2016) supports the idea that valuing the protection of environment, positive feelings about environmentally sensitive activities and expecting positive results from these activities can facilitate the demonstration of environmentally sensitive behaviors. Many authors and institutions have acknowledged that global sustainability requires changes in human values, attitudes and behaviors (Dunlap et al., 2000; Bonnes \& Bonaiuto, 2002; DEFRA, 2003).

Environmental education researchers believe that through environmental and sustainability education, teachers can play an important role in increasing school-level capacity for sustainability (Ferreira et al., 2009; Ferreira, Ryan, \& Tilbury, 2006). They argue that by incorporating environmental/sustainability education into pre-school teacher education, pre-service teachers will graduate with the capacity to place environmental/sustainability education in their daily activities and will therefore be able to make it widespread in schools (Ferreira et al., 2006; Tilbury et al., 2005). However, to date, few teacher education institutions have incorporated sustainability education into pre-service teacher training courses. As a result, many new teachers are graduating with limited understanding, capacity and confidence to implement environmental and sustainability education (Miles et al., 2006).

Assuming that motivation and skills of teachers are important for Education for Sustainability (EFS) (Kennelly, Taylor, \& Maxwell, 2008) and that the experiences lived during the initial teacher training are permanent (Flores \& Day, 2006), pre-service teacher training may facilitate EFS acquisition of future teachers. Investigating the different ways pre-service teachers understand the concept of EFS creates an entry point to integrate sustainability education into teacher education programs. Shepherd (2008), emphasizing the importance of attitudes in EFS, states that a central element of EFS is the exploration of emotional learning outputs of values and attitudes. Osborne, Simon, and Collins (2003) focus on the idea that interest in science is one of the positive attitudes created by formal science education and interacting with EFS will result in pre-service teachers' developing a positive attitude toward sustainability.

When the relevant literature was revived, it was found that in recent years there has been much research focusing on different aspects of education for sustainable development. For example, Arbuthnott (2009) investigated the relationship between attitude and behavior and the effect of the factors directing this relationship on ESD programs; Biasutti and Frate (2017) conducted a study to develop a quantitative scale to evaluate Italian university students' attitudes towards sustainable development; Michalos et al. (2009) explored the attitudes, knowledge and behaviors of Manitoban adults and 6th-12th grade students towards sustainable development; Sahin et al. (2012) looked at the effect of attitudes and values on university students' sustainability-related behaviors; Drayson et al. (2014) investigated the first and second grade students' attitudes and skills related to sustainable development; Spiropoulou et al. (2007) explored the environmental perceptions of the Greek teachers having in-service training and their attitudes towards education on sustainable development; Gürbüz, Çakmak and Derman (2013) investigated the pre-service biology teachers' attitudes towards sustainable development in relation to gender, grade level and source of having access to environmental information; Torbjörnsson, Molin, and Karlberg (2011) explored the adolescents' attitudes towards sustainability; Kwabena (2016) conducted a 
study to understand the psychological obstacles in front of sustainable development of Ghana and the importance of education in terms of affecting attitudes and knowledge in relation to issues of sustainability; Aziz et al. (2012) investigated the importance of basic knowledge about sustainability; Tomas, Girgenti and Jackson (2017) looked at the attitudes of pre-service teachers towards education for sustainability and the effect of the given trainings on pedagogical applications.

The studies conducted on teachers and pre-service teachers' attitudes towards and beliefs about education for sustainability in recent years focus on the place of the discourse of social gender equality within the framework of the targets of sustainable development (Sharma, 2016), whether pre-service teacher training programs can be a tool for making sustainability more widespread (Ferreira et al., 2009); the effect of pre-service teachers' self-reported ESD on self-efficacy and their attitudes towards ESD (Evans, Tomas, \& Woods, 2016); variables affecting how pre-service teachers understand the concept of education for sustainability (Evans et al., 2012); development of sustainability kit (Gardner, 2017).

Ajzen (2002, p. 5) defines attitudes towards behavior as "a person's general positive or negative evaluations related to exhibition of the behavior". More clearly the attitude towards behavior is the positive or negative evaluation of the individual in achieving a specific behavior of interest (Ajzen, 2005). Attitudes can be influenced by consumption choice behavior; for example, people's desires may be stronger than their beliefs, and thus have a negative attitude towards sustainability while they believe sustainability is a cause. Education and knowledge about sustainability play an important role in the development of positive attitudes towards sustainability (Watling \& Zhou, 2011). Thus, pre-service teachers having positive attitudes towards sustainable environmental education can educate their prospective students as individuals with positive attitudes and behaviors towards sustainable life with their classroom applications. The effectiveness of their classroom activities and applications can be enhanced. Future generations should be educated on sustainable topics and strategies in today's consumer society culture. Focusing on the development of sustainability education can lead to emergence of a society in which young people can main their lifestyles in a sustainable way. Well-trained pre-service teachers are needed in order to make sustainability education more widespread. It seems to be necessary to determine pre-service teachers' both cognitive and affective characteristics to make a comprehensive revision of teacher training programs. Attitude is one of these characteristics. Therefore, the current study aims to investigate the pre-service science teachers' attitudes towards sustainable environmental education.

\subsection{Sub-Problems}

a. Do the pre-service science teachers' scores of attitudes towards sustainable environmental education vary significantly depending on gender?

b. Do the pre-service science teachers' scores of attitudes towards sustainable environmental education vary significantly depending on grade level?

c. What is the level of the pre-service science teachers' scores of attitudes towards sustainable environmental education?

\section{Method}

The study employed the descriptive survey method. Survey models aim to describe a situation as it was in the past or it is at present.

\subsection{Participants}

The study group of the current research is comprised of 154 pre-service teachers (1st year-4th year) attending the Department of Science Education in Aksaray University. Of the participating pre service teachers, $72.5 \%$ are females and $27.5 \%$ are males. Of the preservice teachers, 27.3 are first-year students, $22.7 \%$ are second-year students, $20.1 \%$ are third-year students and $29.9 \%$ are fourth-year students.

\subsection{Data Collection Tools}

In order to collect data, "Sustainable Environment Education Attitude Scale" developed by Afacan and Demirci Güler (2011) was used. The original scale consists of 30 items designed in the form of five-point Likert scale ranging from "Strongly Disagree: 1" to "Strongly Agree: 5". The minimum score to be taken from the scale is 30 and maximum score is 150 . The scale used in the study consists of six dimensions. These dimensions are; Awareness of Sustainable Environment, Negative Opinions about Sustainable Environment, Voluntariness, Thriftiness, Sensitivity and Economical Consumption. In the original study, the cronbach alpha reliability 
coefficient of the scale was found to be 0.90 . The calculated Cronbach alpha value of the scale was found to be $\alpha=.93$.

\subsection{Analysis}

SPSS program package was used for the statistical analysis of the data. In the analysis of the data, descriptive statistics, for comparisons, Independent Samples t-test and One Way ANOVA were employed.

\section{Results}

T-test results related to the pre-service science teachers' sustainable environmental education attitude mean scores are given in Table 1.

Table 1. T-test results related to the pre-service science teachers' sustainable environmental education attitude mean scores

\begin{tabular}{|c|c|c|c|c|c|c|c|}
\hline Dependent Variable & Gender & $\mathrm{N}$ & Mean & Std. Deviation & df & $\mathrm{t}$ & Sig. \\
\hline Sustinable Environmental Education & Female & 111 & 116,23 & 18,494 & \multirow{2}{*}{151} & \multirow{2}{*}{1,787} & \multirow{2}{*}{,076 } \\
\hline Attitude Score & Male & 42 & 110,21 & 18,881 & & & \\
\hline
\end{tabular}

As can be seen in Table 1, the female students' sustainable environmental education attitude mean score $(M=116.23)$ is higher than that of the male students $(M=110.21)$. The difference between the female and male students' mean attitude scores is 6.02 in favor of the female students and this difference isn't statistically significant $\left(\mathrm{t}_{(151)}=1.787 ; \mathrm{p}>.05\right)$.

The second sub-problem of the study looked at the correlation between the pre-service science teachers' sustainable environmental education attitude scores and the grade level variable. As can be seen in Table 2, with the students' increasing grade level, their sustainable environmental education attitude scores also increase $(\mathrm{M}=102.80,117.71,118.77$ and 120.34 , respectively).

Table 2. Descriptive statistics related to the pre-service science teachers' sustainable environmental education attitude scores in relation to grade level

\begin{tabular}{lcccc}
\hline \multicolumn{1}{c}{ Dependent Variable } & Grade Level & N & Mean & Std. Deviation \\
\hline Sustinable & 1 & 42 & 102,80 & 20,931 \\
Environmental & 2 & 35 & 117,71 & 16,425 \\
Education Attitude & 3 & 31 & 118,77 & 15,171 \\
Scores & 4 & 46 & 120,34 & 15,759 \\
& Total & 154 & 114,64 & 18,691 \\
\hline
\end{tabular}

Levene test conducted to test the homogeneity of the variances belonging to the data revealed that the variances are not homogenous $(\mathrm{p}<.05)$ (Table 3$)$.

Table 3. Test of homogeneity of variances

\begin{tabular}{cccc}
\hline Levene Statistic & df1 & df2 & Sig. \\
\hline 3,228 & 3 & 150 &, 024 \\
\hline
\end{tabular}

As can be seen in Table 4, the grade level-based difference between the pre-service science teachers' sustainable environmental education mean scores was found to be significant as a result of the variance analysis $\left(\mathrm{F}_{(3-150)}=9.109\right.$; $\mathrm{p}<.001)$. 
Table 4. ANOVA results related to the pre-service science teachers' sustainable environmental education attitude scores in relation to grade level

\begin{tabular}{lccccc}
\hline Source of Variance & Sum of Squares & df & Mean Square & F & Sig. \\
\hline Between Groups & 8237,592 & 3 & 2745,864 & & \\
Within Groups & 45217,473 & 150 & 301,450 & 9,109 & \multirow{2}{*}{000} \\
Total & 53455,065 & 153 & & & \\
\hline
\end{tabular}

* Sig. $<0.001$

Because the variances belonging to the research data is not homogenous, Dunnett $\mathrm{C}$ multiple comparison test was preferred (Table 5).

Table 5. The results of Dunnett C multiple comparison test

\begin{tabular}{|c|c|c|c|c|c|}
\hline \multirow{2}{*}{$\begin{array}{c}\text { (I) Grade } \\
\text { Level }\end{array}$} & \multirow{2}{*}{$\begin{array}{l}\text { (J) Grade } \\
\text { Level }\end{array}$} & \multirow{2}{*}{ Mean Difference (I-J) } & \multirow{2}{*}{ Std. Error } & \multicolumn{2}{|c|}{$95 \%$ Confidence Interval } \\
\hline & & & & Lower Bound & Upper Bound \\
\hline \multirow{3}{*}{1} & 2 & $-14,90476^{*}$ & 4,25907 & $-26,3509$ & $-3,4586$ \\
\hline & 3 & $-15,96467^{*}$ & 4,22568 & $-27,3523$ & $-4,5770$ \\
\hline & 4 & $-17,53830^{*}$ & 3,97875 & $-28,1784$ & $-6,8982$ \\
\hline \multirow{3}{*}{2} & 1 & $14,90476^{*}$ & 4,25907 & 3,4586 & 26,3509 \\
\hline & 3 & $-1,05991$ & 3,89021 & $-11,6015$ & 9,4817 \\
\hline & 4 & $-2,63354$ & 3,62047 & $-12,3623$ & 7,0953 \\
\hline \multirow{3}{*}{3} & 1 & $15,96467^{*}$ & 4,22568 & 4,5770 & 27,3523 \\
\hline & 2 & 1,05991 & 3,89021 & $-9,4817$ & 11,6015 \\
\hline & 4 & $-1,57363$ & 3,58112 & $-11,2336$ & 8,0863 \\
\hline \multirow{3}{*}{4} & 1 & $17,53830^{*}$ & 3,97875 & 6,8982 & 28,1784 \\
\hline & 2 & 2,63354 & 3,62047 & $-7,0953$ & 12,3623 \\
\hline & 3 & 1,57363 & 3,58112 & $-8,0863$ & 11,2336 \\
\hline
\end{tabular}

* The mean difference is significant at the 0.05 level.

As can be seen in Table 5, according to the results of Dunnett $\mathrm{C}$ multiple comparison test, there is a significant difference between the sustainable environmental education attitude mean scores of the 2 nd, 3rd and 4th grade students and that of the 1 st grade students.

The pre-service science teachers' attitudes towards sustainable environmental education seem to be positive and moderately high (Table 6).

Table 6. Descriptive statistics results related to the pre-service science teachers' sustainable environmental education attitude total scores

\begin{tabular}{lccccc}
\hline & \multicolumn{4}{c}{ Descriptive Statistics } \\
\cline { 2 - 5 } & $\mathrm{N}$ & Minimum & Maximum & Mean & Std. Deviation \\
\hline $\begin{array}{l}\text { Total scores of sustainable } \\
\text { environmental education attitude } \\
\text { Valid }\end{array}$ & 154 & 52,00 & 143,00 & 112,5952 & 19,15154 \\
\hline
\end{tabular}




\section{Discussion}

The current study investigated the pre-service science teachers' attitudes towards sustainable environmental education in terms of gender and grade level.

It was found that the pre-service science teachers' scores of attitudes towards sustainable environmental education do not vary significantly by gender. Yet, the female students' mean attitude score was found to be higher than that of the male students. When the relevant literature is reviewed, it is seen that though in general females' attitudes towards sustainable environmental education are more positive, there are also some studies reporting conflicting results. Gürbüz, Çakmak and Derman (2013) found that the pre-service biology teachers' scores of attitudes towards sustainable environment differ significantly in favor of the female participants in the sub-dimensions of "Positive Opinions about Sustainable Environmental Education" and "Sensitivity towards Sustainable Environmental Education". In this regard, it was determined that the female students are worried about urban sprawl and the use of pesticides in agriculture and the possibility of extinction of many animal species in Turkey and they are conscious about purchasing products that can be harmful to environment. Moreover, the female participants were found to be more careful about the use of resources such as energy and water than the male participants. Torbjörnsson, Molin and Karlberg (2011) conducted a study to gain information about 918 secondary school students' attitudes towards sustainability and found no statistically significant difference between the male and female students. Yet, they found that the female students' attitudes towards the protection of nature are stronger than those of the male students. On the other hand, the male students were found to have stronger attitudes towards the exploitation of nature. Both male and female students accepted that they have intention to control nature. One of the remarkable points was that in terms of social solidarity, while $44 \%$ of the female students admitted that they have the responsibility to help poor nations, only $26 \%$ of the male students accepted this responsibility. Findings of Uitto et al. (2003) support the hypothesis that there are differences between the attitudes of boys' and girls' factor scores describing their attitudes towards environmental responsibility. It was concluded that the girls' factor scores determining their attitudes towards environmental responsibility are higher and more positive than those of the boys. These findings concur with Järvinen (1995) stating that Finnish female adolescents aged at 15-17 years old have more positive attitudes than male adolescents (as cited Uitto et al., 2003). Khan and Trivedi (2015) investigate the effect of social gender on the sustainable purchasing behaviors of the consumer in the United Arab Emirates. The findings of the study underline the fact that there are gender-based differences in terms of the effective use of resources, minimization of waste and optimization of scarce resources. The findings also showed that women have a greater tendency towards purchasing products that contribute to the protection of energy and other natural resources. Heinzle and Känzig (2010) point out that women attach greater importance to making sustainable purchasing decisions. Zelezny et al. (2000) reported findings indicating that men are more worried about environment; thus, focus more on sustainable consumption. Torgler et al. (2008) conducted a comprehensive study in western and eastern European countries and reported that women are more willing to make contributions to the protection of environment. Empacher et al. (2000) explored gender-based difference in consumption patterns and found that while men are more oriented towards comfort, women are more oriented towards health and environment.

In light of the findings reported in the literature, it can be argued that while women are more sensitive about solidarity, protection and responsible behaviors towards environment, men are more tended to controlling nature and exploiting natural resources.

The second sub-problem of the current study aims to investigate whether the pre-service teachers' scores of attitudes towards sustainable environmental education vary significantly depending on grade level. It was found that the pre-service teachers' attitude scores increase with increasing grade level. The grade level-based differences between the mean attitude scores of the students were found to be significant. The highest mean attitude score belongs to the fourth-year students. Moreover, a significant difference was found between the mean scores of the 2nd, 3rd and 4th year students and that of the 1st year students. Gürbüz, Çakmak and Derman (2013); in their study on the pre-service biology teachers, found that the scores taken from the sub-dimensions of "Consciousness about Sustainable Environment" and "Voluntariness" by the fifth-year pre-service teachers are significantly higher than the others and the first-year pre-service teachers are more sensitive about the use of energy and recyclable paper. Özdemir and Arık (2013) also found that the students' attitudes towards sustainable environment vary significantly in favor of 8th grade students. With students' increasing grade level, their attitudes towards sustainable environment were also observed to be increasing. In a study looking at the relationship between the pre-service geography teachers' attitudes towards environment and grade level, a significant difference was found between the environmental attitudes mean scores of the first-year students and fourth-year students (Aydın \& Ünaldı, 2015). 
In light of these findings, it is thought that the elective courses taken by students about environmental science, environmental education and sustainable education positively affect their attitudes towards sustainable life with increasing grade level. This indicates that pre-service teachers need to be trained about education for sustainability and therefore, more content about education for sustainability should be integrated into teacher training programs together with suitable learning and teaching strategies. The findings of the study also reveal the importance of focusing on affective dimensions such as attitude for sustainable life.

In light of the findings of the study, it can be suggested that further research can attempt to determine the attitudes of pre-service teachers from different branches and to analyze different factors affecting attitude.

\section{References}

Afacan, Ö., \& Demirci Güler, P. M. (2011). Sürdürülebilir çevre eğitimi kapsamında tutum ölçeği geliştirme çallşması. 2nd International Conference on New Trends in Education and Their Implications, 27-29 April, Antalya, Turkey.

Ajzen, I. (2002). Residual effects of past on later behavior: Habituation and reasoned action perspectives. $\begin{array}{lllll}\text { Personality and Social } & \text { Psychology }\end{array}$ https://doi.org/10.1207/S15327957PSPR0602_02

Ajzen, I. (2005). Attitudes, Personality and Behavior (2nd ed.). Open University Press, New York, USA. Retrieved from https://psicoexperimental.files.wordpress.com/2011/03/ajzeni-2005-attitudes-personality-and-behaviour-2n d-ed-open-university-press.pdf

Arbuthnott, D. K. (2009). Education for sustainable development beyond attitude change. International Journal of Sustainability in Higher Education, 10(2), 152-163. https://doi.org/10.1108/14676370910945954

Aydın, F., \& Ünaldı, E. Ü. (2015). Coğrafya Öğretmen Adaylarının Sürdürülebilir Çevreye Yönelik Tutumları (Geography Teacher Candidates' Attitudes Towards Sustainable Environment). Kalem Uluslararası Ĕgitim ve İnsan Bilimleri Dergisi, 3(1), 11-42. https://doi.org/10.23863/kalem.2017.18

Aziz, A. A., Sheikh, S. N. S., Yusof, K. M., Udin, A., \& Yatim, J. M. (2012). Developing a structural model of assessing students' knowledge-attitudes towards sustainability. Procedia-Social and Behavioral Sciences, 56, 513-522. https://doi.org/10.1016/j.sbspro.2012.09.683

Biasutti, M., \& Frate, S. (2017). A validity and reliability study of the Attitudes toward Sustainable Development scale. Environmental Education Research, 23(2), 214-230. https://doi.org/10.1080/13504622.2016.1146660

Bonnes, M., \& Bonaiuto, M. (2002). Environmental psychology: From spatial-physical environment to sustainable development. In R. B. Bechtel, \& A. Churchman (Eds.), Handbook of Environmental Psychology (pp. 28-54). New York: Wiley.

Christie, B. A., Miller, K. K., Cooke, R., \& White, J. G. (2013). Environmental Sustainability in Higher Education: How Do Academics Teach? Environmental Education Research, 19(3), 385-414. https://doi.org/10.1080/13504622.2012.698598

Corcoran, P. B., \& Wals, A. E. (2004). Higher Education and the Challenge of Sustainability. Dordrecht: Kluwer Academic Publishers. https://doi.org/10.1007/0-306-48515-X

Cortese, A. D. (2003). The Critical Role of Higher Education in Creating a Sustainable Future. Planning for Higher Education, 31(3), 15-22.

Cotton, D. R. E., Warren, M. F., Maiboroda, O., \& Bailey, I. (2007). Sustainable development, higher education and pedagogy: A study of lecturers' beliefs and attitudes. Environmental Education Research, 13(5), 579-597. https://doi.org/10.1080/13504620701659061

DEFRA. (2003). Changing Patterns - UK Government Framework for Sustainable Consumption and Production. PB 8733, September, DEFRA Publications, UK.

Drayson, R., Bone, E., Agombar, J., \& Kemp, S. (2014). Student attitudes towards and skills for sustainable development. The Higher Education Academy, November.

Dunlap, R. E., Van Liere, K. D., Mertig, A. G., \& Jones, R. E. (2000). Measuring endorsement of the new ecological paradigm: A revised NEP scale. Journal of Social Issues, 56(3), 425-442. https://doi.org/10.1111/0022-4537.00176 
Empacher, C., Hayn, D., Schubert, S., \& Schultz, I. (2001). Analyse der Folgen des Geschlechtsrollenwandels für Umweltbewusstsein und Umweltverhalten. Retrieved June 5, 2017, from http://www.isoe.de/forschung/foaktuellf.htm

Evans, N. S., Whitehouse, H., \& Hickey, R. (2012). Pre-service Teachers' Conceptions of Education for Sustainability. Australian Journal of Teacher Education, 37(7). https://doi.org/10.14221/ajte.2012v37n7.3

Evans, N., Stevenson, R., Ferreira, J. A., \& Davis, J. M. (2016). Embedding EfS in teacher education through a multi-level systems approach: Lessons from Queensland. Australian Journal of Environmental Education, 32(S1), 65-79. https://doi.org/10.1017/aee.2015.47

Ferreira, J. A., Ryan, L., \& Tilbury, D. (2006). Whole-School Approaches to Sustainability: A review of models for professional development in pre-service teacher education. Canberra: Department of the Environment and Heritage and the Australian Research Institute in Education for Sustainability.

Ferreira, J., Ryan, I., Davis, J., Cavanagh, M., \& Thomas, J. (2009). Mainstreaming sustainability into Pre-service teacher education in australia. Canberra: Prepared by the australian research institute in education for sustainability for the australian government department of the environment, Water, heritage and the arts.

Flores, M. A., \& Day, C. (2006). Contexts which shape and reshape new teachers identities: A multi-perspective study. Teaching and Teacher Education, 22, 29-232. https://doi.org/10.1016/j.tate.2005.09.002

Gardner, A. A. (2017). Sustainability Toolkit: An Educational Tool For Behavioral Change Strategies (Master of Science Thesis). School of Architecture, The University of Arizona.

Gürbüz, H., Çakmak, M., \& Derman, M. (2013). Biyoloji Öğretmen Adaylarının Sürdürülebilir Çevreye Yönelik Tutumları (Biology Teachers'Attitudes Towards Sustainable Environment). Türk Bilimsel Derlemeler Dergisi, 6(1), 144-149.

Heinzle, S., Kanzig, J., Nentwich, J., \& Offenberger, U. (2010). Moving beyond gender differences in research on sustainable consumption: Evidence from a discrete choice experiment. Retrieved July 10, 2017, from http://kooperationen.zew.de/fileadmin/user_upload/Radaktion/Seco@home/nachhaltiger_Energiekonsum/ Werkstattberichte/Gend er_Werkstattbericht6.pdf

Järvinen, M. (1995). Ympäristöystävä vai vapaamatkustaja? Tutkimus nuorten ympäristöasenteista. In Suomen ympäristö. Ympäristöpolitiikka 1. Helsinki: Suomen ympäristökeskus.

Kennelly, J., Taylor, N., \& Maxwell, T. (2008a). A Student Teacher's Personal Pathway to Education for Sustainability. Australian Journal of Environmental Education, 24, 23-33. https://doi.org/10.1017/S0814062600000550

Kennelly, J., Taylor, N., \& Maxwell, T. (2008b). Addressing the Challenge of Preparing Australian Pre-service Primary Teachers in Environmental Education: An Evaluation of a Dedicated Unit. Journal of Education for Sustainable Development, 2(2), 141-156. https://doi.org/10.1177/097340820800200211

Khan, N., \& Trivedi, P. (2015). Gender Differences ans sustainable consumption behaviour. British Journal of Marketing Studies, 3(3), 29-35.

Kwabena, A. O. (2016). Development of a Structural Model Based Upon the Theory of Planned Behavior to Assess Ghanaians' Intentions, Attitudes, and Knowledge Regarding Sustainability (Ph.D. Dissertation). Doctor of Philosophy Graduate School of Maharishi University of Management, Fairfield, Iowa.

Lautensach, A. K., \& Lautensach, S. W. (2010). Teaching for sustainability: Curriculum reform in the age of environmental injustice. International Journal of Arts and Sciences, 3(14), 195-214.

Michalos, A. C., Creech, H., McDonald, C., \& Kahlke, P. M. H. (2009). Measuring knowledge, attitudes and behaviours towards sustainable development: Two exploratory studies. Winnipeg, Canada: International Institute for Sustainable Development.

Miles, R., Harrison, L., \& Cutter-Mackenzie, A. (2006). Teacher education: A diluted environmental education experience. Australian Journal of Environmental Education, 22(1), 49-59. https://doi.org/10.1017/S0814062600001658

Nolet, V. (2009). Preparing sustainability-literate teachers. Teachers College Record, 111(2), 409-442. 
Osborne, J., Simon, S., \& Collins, S. (2003). Attitudes towards Science: A Review of the Literature and Its Implications. International Journal of Science Education, 25(9), 1049-1079. https://doi.org/10.1080/0950069032000032199

Orr, D. W. (2003). Walking north on a southbound train. Conservation Biology, 17(2), 348-351. https://doi.org/10.1046/j.1523-1739.2003.01722.x

Özdemir, B. E., \& Arık, S. (2013). Ortaokul Öğrencilerinin Benlik Saygı Düzeylerinin ve Sürdürülebilir Çevreye Yönelik Tutumlarının İncelenmesi (The investigation self-esteem levels and attitudes towards a sustainable environment of the secondary school students). Journal of History School, 6(XVI), 641-655.

Sahin, E., Ertepınar, H., \& Teksoz, G. (2012). University students' behaviors pertaining to sustainability: A structural equation model with sustainability-related attributes. International Journal of Environmental and Science Education, 7(3), 459-478.

Sharma, B. B. (2016). Sustainable Gender Equality Framework: A Justice Perspective (PhD). The University of Texas at Arlington.

Shephard, K. (2008). Higher Education for Sustainability: Seeking Affective Learning Outcomes. International Journal of Sustainability in Higher Education, 9(1), 87-98. https://doi.org/10.1108/14676370810842201

Spiropoulou, D., Antonakaki, T., Kontaxaki, S., \& Bouras, S. (2007). Primary Teachers' Literacy and Attitudes on Education for Sustainable Development. $J$ Sci Educ Technol, 16, 443-450. https://doi.org/10.1007/s10956-007-9061-7

Stuckey, D. B. (2016). Choosing Sustainability: The Relationship Between Personal Standards and Environment Responsive. Department of Counseling, Adult and Higher Education, Doctor of Education, Northern Illinois University.

Thomas, I. (2004). Sustainability in Tertiary Curricula: What is Stopping It Happening? International Journal of Sustainability in Higher Education, 5(1), 33-47. https://doi.org/10.1108/14676370410517387

Tilbury, D., Coleman, V., \& Garlick, D. (2005). A National Review of Environmental Education and its Contribution to Sustainability in Australia: School Education. Canberra: Department of the Environment and Heritage and Australian Research Institute in Education for Sustainability (ARIES).

Tomas, L., \& Mills, R. (2011). Pre-service Teachers' Understanding and Concern for Sustainability Issues: Implications for Teacher Education. In Proceedings of the Australian Teacher Educators' Association 2011 Conference, 1-7. From: Valuing Teacher Education: Policy, Perspectives and Partnerships, Melbourne, Australia, July 3-6.

Tomas, L., Girgenti, S., \& Jackson, C. (2017). Pre-service teachers' attitudes toward education for sustainability and its relevance to their learning: Implications for pedagogical practice. Environmental Education Research, 23(3), 324-347. https://doi.org/10.1080/13504622.2015.1109065

Torbjörnsson, T., Molin, L., \& Karlberg, M. (2011). Measuring attitudes towards three values that underlie sustainable development. Utbildning \& Demokrati, 20(1), 97-121.

Torgler, B., Valiñas, M. A. G., \& Macintyre, A. (2008). Differences in Preferences Towards the Environment: The Impact of a Gender, Age and Parental Effect. FEEM Working Paper, 18. https://doi.org/10.2139/ssrn.1105320

Uitto, A., Juuti, K., Lavonen, J., \& Meisalo, V. (2003). Who is responsible for sustainable development? In Attitudes to environmental challenges: A survey of Finnish 9th grade comprehensive school students. Retrieved July 20, 2017, from http://roseproject.no/network/countries/finland/fin-uitto-2003.pdf

Wals, J. E. A., \& Jickling, B. (2002). "Sustainability" in Higher Education: From doublethink and newspeak to critical thinking and meaningful learning. Higher Education Policy, 15(2), 121-131. https://doi.org/10.1016/S0952-8733(02)00003-X

Watling, A., \& Zhou, E. (2011). Attitudes Towards Sustainability: A Quantitative Study of Sustainable Ålidhem. Retrieved from https://www.diva-portal.org/smash/get/diva2:430152/FULLTEXT01.pdf

Zelezny, L. C., Poh-Pheng, C., \& Aldrich, C. (2000). Elaborating on Gender Differences in Environmentalism. Journal of Social Issues, 56(3), 443-457. https://doi.org/10.1111/0022-4537.00177 


\section{Copyrights}

Copyright for this article is retained by the author(s), with first publication rights granted to the journal.

This is an open-access article distributed under the terms and conditions of the Creative Commons Attribution license (http://creativecommons.org/licenses/by/4.0/). 